Winter 2008

\title{
Reconstructing Contemporary Democracy
}

Jan Aart Scholte

University of Warwick

Follow this and additional works at: https://www.repository.law.indiana.edu/ijgls

Part of the Civil Law Commons, and the International Law Commons

\section{Recommended Citation}

Scholte, Jan Aart (2008) "Reconstructing Contemporary Democracy," Indiana Journal of Global Legal Studies: Vol. 15 : Iss. 1 , Article 13.

Available at: https://www.repository.law.indiana.edu/ijgls/vol15/iss1/13

This Symposium is brought to you for free and open access by the Law School Journals at Digital Repository @ Maurer Law. It has been accepted for inclusion in Indiana Journal of Global Legal Studies by an authorized editor of Digital Repository @ Maurer Law. For more information, please contact rvaughan@indiana.edu.

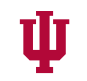

JEROME HALL LAW LIBRARY

INDIANA UNIVERSITY

Maurer School of Law
Blooming ton 


\title{
Reconstructing Contemporary Democracy
}

\author{
Jan Aart Scholte*
}

Abstract

Democratic practice varies historically, and transformations of the societal context require accompanying reconstructions of democracy if "rule by the people" is to remain meaningful. Contemporary society is witnessing particularly profound changes in underlying structures of space, governance, and identity. Fundamental reconsideration of democracy is therefore also needed. This article first develops a generic understanding of democracy; next elaborates on currently unfolding transformations of geography, regime, and community; and then develops a five-faceted reconstruction of democracy to meet these changed circumstances. This prescription entails: (1) reconceptualizing democracy, shifting away from obsolete assumptions of territorialist space, statist regulation, and nationalist identity; (2) refashioning civic education to empower all citizens to act in this new situation; (3) building effective institutional mechanisms of public accountability in respect of an emergent polycentric mode of governance; (4) effecting progressive structural redistributions of resources and power in order that all stakeholders in contemporary public policy issues have more equal opportunities of political participation; and (5) nurturing positive practices of intercultural recognition, communication, and negotiation.

\section{INTRODUCTION}

Like any aspect of social relations, democracy varies historically. Rule (kratia) by the people (demos) has taken substantially different forms across time and place. Indeed, to be effective, modes of democracy must shift in line with wider social transformations. Practices that advance collective self-determination at one

* Professorial Research Fellow in the Centre for the Study of Globalisation and Regionalisation, University of Warwick and Centennial Professor, Centre for the Study of Global Governance, London School of Economics. This article was largely prepared during an appointment as Olof Palme Guest Professor at the School of Global Studies, Gothenburg University, 2006-2007, funded by the Swedish Research Council.

Indiana Journal of Global Legal Studies Vol. $15 \# 1$ (Winter 2008)

OIndiana University School of Law 
historical juncture can become inadequate or even obsolete altogether with changes in the deeper structures of society.

In threefold fashion democracy always relates to, and interlinks, a geographical space, a governance apparatus, and a collective identity. Democratic practice varies in accordance with different constructions of place, regime, and community. When historical developments alter the "where," the "what," and the "who" in this equation, formulas of democracy must correspondingly change apace if "rule by the people" is to be meaningful in the new circumstances.

World-historical trends of the past half-century are bringing significant reconfigurations of these three primary aspects of social structure. In terms of geography, an earlier fixation on the country as the spatial unit of society is (through concurrent processes of globalization, regionalization, and localization) giving way to more fluid transscalar domains. In terms of governance, an earlier concentration on the state as the channel for the administration of societal rules is giving way to regulation through polycentric networks. In terms of collective identity, an earlier focus on the nation as the overriding framework of affiliation and solidarity in society is giving way to plural communities. Hence, while earlier democratic practice was constructed around the interconnection of country, state, and nation, contemporary democracy wants reconstruction around the interconnection of transscalar space, polycentric governance, and plural collective identity.

The question then arises how to accomplish such a reconstruction. A number of contemporary political theorists have addressed different aspects of the challenge. For example, cosmopolitan thinkers have highlighted a need to take democracy beyond the country sphere.' Multilateralists have stressed a need to bolster the democratic legitimacy of suprastate governance institutions with regional and global jurisdictions. ${ }^{2}$ Critical political economists have focused on a need to counter material inequalities that hamper democratic participation and control for much of hu-

1. See David Held, Democracy and the Global Order: From the Modern State to Cosmopolitan Governance (Polity Press 1995); Andrew Linklater, The Transformation of Political Community: Ethical Foundations of the Post-Westrhalian Era (Polity Press 1998); James Bohman, Republican Cosmopolitanism, 12 J. of Pol. PHIL. 326, 336-52 (2004).

2. See Michael Zürn, Democratic Governance Beyond the Nation-State: The EU and Other International Institutions, 6 EUr. J. of INT'L Rel. 183; Allan Buchanan \& Robert O. Keohane, The Legitimacy of Global Governance Institutions, 20 ETHics \& INT'L AfF. 405 (2006). 
manity. ${ }^{3}$ Poststructuralists have emphasized a need in a more plural society to relate democracy not only to the nation, but also to other collective identitics. ${ }^{4}$

Arguably, a more comprehensive reconstruction of democracy would interlink these various projects in a single endeavor. On this inspiration the present essay outlines a fivefold strategy for democratic revival. In this design a first core task is to reconceptualize democracy, taking distance from the methodological territorialism, methodological statism, and methodological nationalism that have previously framed modern notions of "rule by the people." A second task is to develop modes of civic education that make all persons critically aware of the altered ways that society is now ordered, and could be further reordered. A third task is to build effective institutional mechanisms of public accountability for the emergent polycentric mode of governance. A fourth task is to implement progressive redistributions of world resources and power in order that people have veritably more equal opportunities of political involvement. A fifth task, given the rise of plural collective identities, is to nurture positive practices of intercultural recognition, communication, and negotiation. These five exercises in reconstructing democracy must be undertaken in tandem, with each contributing to and drawing upon the others. Thus, for example, new initiatives in civic education would convey new understandings of democracy and promote positive interculturality, while new mechanisms of public accountability would operate in ways that reduce arbitrary social inequalities.

The rest of this article develops the argument just summarized. The next section below takes the initial step of setting out a general conception of democracy and its pivotal role in a good society. A further section then expands on the contemporary transformations of geography, governance, and collective identity that call forth new modes of democratic practice. Thereafter the discussion elaborates the five-faceted reconstruction of democracy introduced above, before concluding remarks note the main contemporary social forces that can facilitate and/ or frustrate the realization of such a project.

3. See Stephen Gill, Power and Resistance in the New World Order (2003); Ronaldo Munck, Globalisation and Contestation: The New Great Counter-Movement (2007).

4. See William E. Connolly, The Exhos of Pluralization (1995); Critical Theories, INternational Relations and 'The Anti-Globalization Movement': The Politics of Global Resistance (Catherine Eschle \& Bice Maiguashca eds., 2005); Rob B.J. Walker, On the Spatiotemporal Conditions of Democratic Practice, in Inside/Outside: International Relations as PolitiCAL TheORY 141-58 (1993). 


\section{Democracy}

The meaning and value of democracy are so generally accepted as commonsense in society today that it could seem superfluous to address these issues explicitly. Yet the merits of democracy can be forgotten if they are not regularly reiterated. Indeed, situations where democracy is taken for granted are ripe for its subversion. If political subjects do not continually affirm their own ideas and practices of democracy, hegemonic power is ever ready to co-opt the rhetoric for its own antidemocratic purposes, as is apparent across much (if not most) of the contemporary world.

Several cautions are suitably highlighted when formulating a counter-hegemonic conception of democracy. One is that the definition must not be imposed by elite decree. In this light, a trade unionist in Bangkok cautions that "definitions of democracy should not be controlled by academics and legal experts. The poor must also say what they mean and want by democracy." $\mathrm{A}$ second caution is that the definition must not be culturally exclusionary. In this vein, the head of a Parisbased think tank argues that "we must conceive of a mode of democracy that is compatible with the legal and cultural diversity of the world. Everyone has to feel at ease in their tradition."

Therefore, a critical emancipatory notion of democracy is one that resonates across social strata and cultural life-worlds, including subordinated circles in particular. To this end, the present analysis has, methodologically, evolved mainly through conversations on the shape of current and future democracy with around four hundred citizen activists in highly diverse situations around the world. ${ }^{7}$ The range of informants has encompassed, among many others, dispossessed fisher folk in northeastern Thailand, indigenous women in Amazonia, a mental health campaign in eastern Uganda, an antiracism initiative in Paris, consumer advocates in Russia, Islamic revivalists in Egypt, and business executives in Canada. To be sure, the analysis has still been performed through the context-bound filters of

5. Interview with Somsak Kosaisook, President, State Railway Workers Union of Thailand, in Bangkok, Thail. (June 12, 2002).

6. Interview with François-Xavier Verschave, President, Survie (Survival), in Paris, Fr. (Dec. $10,2001)$.

7. The discussions took place between November 2001 and August 2005. Grant support for this work from the Ford Foundation is gratefully acknowledged. See Jan Aart Scholte, Democratizing the Global Economy: The Role of Civil Society (Centre for the Study of Globalisation and Regionalisation, 2004), available at http://www2.warwick.ac.uk/fac/soc/csgr/research/ projects/englishreport.pdf. 
the structurally privileged author. Nevertheless, one may hope that interpretations undertaken with self-critical awareness of those filters may enable a substantially transsectoral and transcultural conception to emerge.

In the present case, dialogues that are deliberately intercultural and proactively hand the microphone to marginalized voices have yielded a definition that democracy prevails when members of a given public decide-collectively, equally, noncoercively, openly, and responsibly — the policies that shape their common life and joint destinies. Several points warrant elaboration here: (a) the notion of "the public" and (b) each of the five adverbs at the heart of this conception.

If democracy means self-rule by a public (alternatively described as a "people" or a "demos"), what comprises that entity? John Dewey helpfully suggests that "the public" - and thus "the people" that democracy should address - is the collection of persons whom a given set of transactions affects to such an extent that the consequences need to be cared for. ${ }^{8}$ On similar lines, David Held affirms that "those whose life expectancy and life chances are significantly affected by social forces and processes ought to have a stake in the determination of the conditions and regulation of these."

Adopting such an approach, the contours of "the people" in "rule by the people" would follow what could be called an "affected principle." ${ }^{\prime 0}$ On this basis, one would, in regard to any public policy problem, identify the circle of persons whose lives are substantially shaped by the situation in question. On democratic principles, that collectivity should then guide the policy decision making concerning the problem at hand.

The shared effects that forge a public are both objective and subjective in character. In other words, the bonds that constitute a people involve, and interlink, material as well as ideational aspects. Thus, on the one hand, a demos rests in concrete circumstances, such as residence together in a particular domain, common ecological challenges, deep economic interdependence, and/or shared resistance to a given oppression. On the other hand, a public is also formed through experiential circumstances such as shared symbols, common beliefs, and convergent perceptions. These objective and subjective qualities of a demos are interrelated and mutually constitutive: that is, the ecological and economic conditions mold the cultural and psychological conditions, and vice versa. Hence the shape

8. John Dewey, The Public and Its Problems 15-16 (Holt 1927).

9. David Held, Democratic Accountability and Political Effectiveness from a Cosmopolitan Perspective, 39 Gov't \& Opposition 363, 374 (2004).

10. Sofia Näsström, What Globalization Overshadows, 31 Pol. Theory 808, 822-25 (2003). 
of "the people" in democracy shifts with changes in the prevailing material and mental structures in society.

Most modern democratic theory has affirmed that "the public" can be more or less defined as the national population that inhabits a country domain ruled by a state apparatus. However, as is argued later in this essay, the patterns of contemporary social relations do not necessarily correspond to-and indeed often deviate radically from - the contours of country-state-nation units. In such circumstances, the nature of "the people" and the ways that they undertake selfrule require fundamental reconsideration.

Moving on to the adverbs in the proffered definition, democracy prevails when a given public takes decisions collectively. To be sure, reaching collective positions normally requires recognition of - and often delicate negotiations among-majority prerogatives, minority rights, and individual liberties. Moreover, even the most sensitively conducted collective deliberations may not result in consensus across the relevant demos. Yet, whatever the remaining internal divisions, democracy entails that the public in question takes decisions as a whole, with involvement by all.

Second, on the definition adopted here, democracy exists when all persons equipped to participate in the collective decision-taking do so on an equal footing. With certain limited exceptions, such as young children and the mentally incapacitated, everyone in a democracy has equivalent opportunities of involvement. Needless to say, different theories and practices of democracy (e.g., anarchism, feminism, liberalism, and socialism) advance different notions of what constitutes and secures political equality. However, most would agree, in the words of a human rights advocate in Montreal, that "democracy is about giving space for the excluded to have influence in decision-making."

Third, democracy prevails when people engage in collective decision-taking without coercion, by their own conscious choice and initiative. In a democratic condition, no one is overtly forced to participate, forced to exercise their right of participation in narrowly circumscribed ways, or forced to adopt certain policy positions when they do participate. Of course, prevailing social structures tend to set boundaries on the range of political actions that are permitted in a given historical context. However, in a democracy the people as a whole, rather than a narrow ruling circle, determine any limits to freedom. Moreover, anyone in a

11. Interview with Iris Almeida, Director of Programmes, Rights \& Democracy, in Montreal, Can. (Apr. 30, 2002). 
democratic polity has the right to demand justification and review of such constraints as are maintained, and authorities have a duty to address such requests.

Fourth, democracy is conducted in an open, visible, transparent fashion, where all people affected can see what public policy decisions are taken, when, by whom, through what procedures, on the basis of what evidence, drawing on what resources for implementation, and with what expected consequences. With transparency governance is open to thorough scrutiny by those that the regulation impacts. Of course there are situations (such as criminal investigations and advance notice of certain changes to macroeconomic policy) where public interest may require some temporary restrictions on the release of information. However, under democracy the default position is timely and full disclosure, and any exceptions to that rule require thorough justification.

Fifth, in the conception adopted here democracy is both a right and a responsibility for the public in question. Democratic practice combines opportunities with duties, liberties with accountabilities. In this spirit the director of a policy institute in Rio de Janeiro asserts that "democracy means responsibilities as well as rights: responsibility to respect diversity, to fight inequality, and to show solidarity." ${ }^{\prime 2}$ Other commentators might specify the obligations differently, but the general point holds that democracy is a process of socially responsible collective self-determination.

To recapitulate, democracy as conceived here prevails when the people affected by a given societal problem take decisions regarding that issue jointly, equally, freely, transparently, and responsibly. To be sure, the practices through which this package of five principles is enacted can and do vary widely across time, culture, and ideology. ${ }^{13}$ Moreover, the frame of the demos in democracy (i.e., the nature of "the people") can and does shift considerably by context, as is illustrated below in the discussion of changing constructions of political identity in contemporary society. Nevertheless, the definition of democracy set out here brings a unity to this diversity, while also providing sufficient specificity to be analytically and politically meaningful.

And meaningful democracy most definitely needs to be. Although "rule by the people" is not the only measure of a society's worth, a society without substantial democracy is arguably not very worthy. Democratic practice has major intrinsic normative value as a way to promote human dignity, realize human potentials,

12. Interview with Cândido Grzybowski, Director, Brazilian Inst. of Soc. and Econ. Analysis (IBASE), in Rio de Janeiro, Braz. (Jan. 22, 2002).

13. See David Held, Models of Democracy (Polity Press 3d ed., 2006) (1987). 
and build human solidarities. Historical experience suggests that imperial, monarchical, and other authoritarian alternatives to democracy almost invariably encourage abuses of power, place arbitrary restrictions on human growth, and depend for their survival on violence and threats of violence.

In addition to its intrinsic merits, democracy often has positive consequences for other cornerstones of a good society, such as conflict limitation, cultural vibrancy, ecological care, material well-being, morality, and social justice. When people shape their own destiny on a basis of collectivity, equality, freedom, openness, and responsibility, they are more likely to resolve disputes peaceably, to embrace cultural diversity, to ensure that none go needy, to treat one another decently, and to share opportunities and benefits fairly. Democracy thereby encourages constructive co-existence within a polity.

Democracy is not an unproblematic good, of course. Theories and practices of popular self-determination are replete with ambiguities and contradictions. For example, which should take the higher priority in democracy when conflicts arise between rights and responsibilities, between liberty and equality, or between majority preferences and minority protections? In addition, democracy often involves significant efficiency costs in terms of time-consuming and cumbersome decision-taking procedures. Moreover, with poor public education democracy can yield a tyranny of the misguided.

Nor does democracy always benefit other core qualities of a good society. On the contrary, circumstances may sometimes present difficult tradeoffs between democracy and ecological integrity, between democracy and economic productivity, or between democracy and peace. Certain situations may even warrant some sacrifice of democracy for gains in respect of other primary societal values, although in this case, too, the hope would be to decide any such sacrifices by democratic process.

Yet even if democracy is no panacea and sometimes presents problems of its own, on the whole it offers a major positive sum outcome. It may well be that democracy is always pursued and never fully achieved. However, the possible is not reached if the impossible is not attempted. Maximal democracy comes from ceaseless struggles for democracy. A society that is not striving for greater "rule by the people" tends to be more unattractive and dangerous as a result.

\section{Changing Circumstances}

Quests for democracy never end partly because, as previously stressed, the contexts in which rule by the people is to be performed are continually changing. 
No democratic instrument has timeless validity. This maxim holds particularly strongly in the present moment of substantial structural transformations in society. As the following section elaborates, three key elements that shape the context of democracy-structures of space, governance, and collective identity-are all currently undergoing major shifts.

\section{A. Geography: From Countries to Transscalar Spaces}

Democracy always relates to a space. "The people" who exercise self-rule inhabit a place, a domain, a realm. When the geographical contours change (for example, from a village-centered to a country-centered society at other historical junctures), practices of democracy need to be correspondingly reconstructed.

Another significant respatialization of social relations has been unfolding over the past half-century. In this shift, a previous near-exclusive focus on country units has given way to circumstances of multiple and overlapping geographical scales. On the one hand, trends of globalization and regionalization have substantially enlarged the importance of macro social domains that transcend the confines of countries. On the other hand, processes of localization have reaffirmed the autonomous significance of territorially smaller spaces within (or sometimes straddling) country borders. As a result of these developments-together with the continued major, if no longer exclusive, relevance of country realms-society is acquiring a geographically more transscalar character.

Globalization refers here to the growth of social spaces of transplanetary proportions. Global social relations involve direct exchanges and significant interdependencies among persons located anywhere across the earth (hence their "transplanetary" quality). ${ }^{14}$ The many and wide-ranging instances of globality encompass communications (e.g., the internet), travel (e.g., jet airplanes), production (e.g., transborder commodity chains), trade (e.g., transfer pricing), money (e.g., gold and the U.S. dollar), finance (e.g., offshore banking), organizations (e.g., planetspanning religious networks), laws (e.g., various human rights conventions), military affairs (e.g., intercontinental missiles), ecological developments (e.g., climate change), and health problems (e.g., a host of infectious diseases). In addition to these concrete connections, globality is also manifested ideationally, as people conceive of their social existence in transplanetary terms. Such global consciousness extends inter alia to notions of political prerogatives and duties, for example, with principles

14. Jan Aart Scholte, Globalization: A Critical Introduction 41-61 (Palgrave Macmillan $2 \mathrm{~d}$ ed. 2005). 
of human rights and humanitarian assistance that putatively apply anywhere across the planet.

Global social connectivity is by no means new to contemporary history, as various instances such as the world religions, long-distance epidemics, and the slave trade indicate. However, globalization has occurred on an unprecedented scale since the middle of the twentieth century. Transplanetary social relations are now more numerous in quantity, more wide-ranging in type, more frequent in incidence, faster in speed, more intensely experienced, and deeper in impact. As a result, present-day society is qualitatively more global than anything that has come before. One wide-ranging composite measure, the Globalisation Index compiled at the Centre for the Study of Globalisation and Regionalisation (CSGR), suggests that the overall level of global links in the world rose (on a scale $0-1$ ) from 0.23 in 1982 to 0.68 in $2004 .^{15}$ Transplanetary spaces have come to constitute a major site of social life in their own right.

Although globalization has attracted the most academic attention to date, it has not been the only important respatialization unfolding in contemporary history away from a country-centered geography, as the concurrent trend of regionalization indicates. Regionalization refers here to the growth of social spaces that span several contiguous countries. (Another type of "regionalization," namely that within countries, is in the present analysis subsumed under localization.) The dimensions of regions vary considerably. For example, a region can be continental in scope, say, in relation to Africa, Australasia, or North America. On other occasions a region may link the littorals of several continents, as in the Asia-Pacific, the Mediterranean Basin, or the South Atlantic. Still other regions (sometimes termed "sub-regions") encompass part of a continent, like Amazonia, Central Asia, or West Africa. Whatever the proportions, however, common to all regions is a transcendence of country units without extending to a planetary reach. ${ }^{16}$

Contemporary regionalization has occurred in respect of broadly the same sorts of connections that have expanded global social spaces. For example, many companies now organize their production processes and marketing strategies on

15. Centre for the Study of Globalisation and Regionalisation, Globalisation Index, http://www2 .warwick.ac.uk/fac/soc/csgr/index/download (last visited Feb. 28, 2008). See also David Herd et al., Global Transformations: Politics, Economics and Culture (Polity Press 1999); Scholte, supra note 14 , at $62-88$.

16. See Michael Schulz et al., Regionalization in a Globalizing World: A Comparative Perspective on Forms, Actors and Processes (2001). 
largely regional lines. ${ }^{17}$ Money has taken regional forms in currencies such as the CFA franc and the euro as well as with the recent emergence of regional monetary funds in Asia and Latin America. Civil society associations have taken regional shape through initiatives like the European Social Forum and the Inuit Circumpolar Conference. Over 270 regional trade agreements were reported to the World Trade Organization (WTO) by 2003. ${ }^{18}$ Much infrastructure (road and rail networks, radio frequencies, gas pipelines, etc.) has also become organized in good part on a regional basis. And people "think regionally," conceiving of themselves as being, at least in part, African, European, North American, etc. Like globalization, regionalization is not new to the past half-century, as the Holy Roman Empire, historical trade networks in Southeast Asia, and Pan-American movements illustrate. However, the past half-century has seen historically unprecedented extents of regionalization. ${ }^{19}$

Concurrently with respatialization beyond country spheres, through globalization and regionalization, contemporary history has also witnessed considerable reorganization of social geography within countries. This reterritorialization in the direction of smaller realms might be called "localization." Like regions, local spaces come in different shapes and sizes. Some localization has focused on immediate surroundings, for example, in respect of neighborhoods, districts, and municipalities. Urbanization will see the share of humanity living in towns and cities top 50 percent in 2008..$^{20}$ Other localization has occurred in respect of provinces, counties, federal states, or "countries within countries" such as Québec and Scotland. Meanwhile certain other localizations have spanned a borderland between several countries, in cases such as Lapland and the pygmy area of equatorial Africa.

Localized social geography is of course no more new to contemporary history than regional and global social relations. Many towns and provinces predate the countries of which they are a part. However, subcountry spheres have reasserted their significance over the past half-century. The many manifestations of this trend include the proliferation of town-twinning schemes, the development of ex-

17. Allan M. Rugman, The Regional Multinationals: MNEs and "Global" Strategic Management 11-19 (2005).

18. Aaron Cosbey et al., The Rush to Regionalism: Sustainable Development and Regional/Bilateral Approaches to Trade and Investment Liberalization at 2 (International Institute for Sustainable Development, 2004), http://www.iisd.org/publications/pub.aspx?id=670.

19. See Assessment and Measurement of Regional Integration (Philippe de Lombaerde ed., 2006).

20. United Nations Population Fund, State of World Population 2007: Unleashing the Potential of Urban Growth 6 (2007), http://www.unfpa.org/swp/. 
port processing zones, the rise of indigenous peoples' movements, the creation of local currencies, and a host of constitutional devolutions a round the world. Recent recentralization in Russia under President Putin stands out for running against the prevailing grain.

It must be emphasized that these three trends--globalization, regionalization, and localization-do not, singly or together, entail an end to countries as a cornerstone of social geography. This threefold respatialization has certainly attenuated the near-exclusive concentration of social geography on country units that prevailed in the middle of the twentieth century. Yet countries are by no means disappearing. On the contrary, they have arguably further consolidated at the same time that other scales of social geography have also risen in importance. Countries remain highly significant contexts for the organization of production processes, trade and migration flows, communications infrastructure, institutional networks, citizenship, and more. However, countries have moved from being the basic unit of social space to being one of several key dimensions of a more complex social geography.

Hence the contemporary transformation of social geography entails not so much a shift from one scale to another, but rather a shift from a largely uniscalar country-centered circumstance fifty years ago to a far more transscalar situation now. History today is not witnessing the replacement of one center of social geography (the country unit) by any other (be it the globe, the region, or the locality). The different spheres of social organization are not competing to acquire the sort of dominance previously held by country spaces. Rather, localization, nationalization, regionalization, and globalization are unfolding in tandem and involve much mutual reinforcement. The four are complementary aspects of a multifaceted respatialization in the direction of a transscalar social geography. To take but one concrete example, localized indigenous peoples have often advanced their causes through global, regional, and national campaigns. Thus contemporary social relations need to be understood not as having a discrete global, regional, country, or local character, but as entailing a transscalar interplay of these geographical contexts. The concept of "glocalization" conveys the global-local part of this interplay, ${ }^{21}$ but one could equally coin parallel (if more cumbersome) notions of "gregionalization" and "regio-nationalization" to cover other aspects.

This reconfigured geography has far-reaching implications for democracy. "Rule by the people" was suitably constructed in relation to countries at a time

21. Roland Robertson, Glocalization, in Encyclopedia of Globalization 545-48 (Roland Robertson \& Jan Aart Scholte eds., 2006). 
when these territorial units were the comprehensively overriding site of collective life. Yet when social space is being restructured on transscalar lines, a mode of democracy that remains restricted to a country matrix is obsolete. The suitable response in these circumstances is not to relocate "rule by the people" from the country sphere to some other "level." In this vein some cosmopolitans have suggested elevating democracy to the global level, while some localists have advocated devolution to self-determining neighborhoods and villages. ${ }^{22}$ Yet such exercises attempt to resituate democracy in a new center, when a defining feature of the emergent social geography is its decentered character. What is needed, therefore, is a reconstruction of democracy that covers global, regional, country, and local domains in transscalar combination.

\section{B. Governance: From Statism to Polycentrism}

The contemporary reconfiguration of geography described above is reflected in, and reinforced by, a concurrent reconstruction of the general mode of governance. Much as the contours of societal space have shifted over the past half-century, so have the institutional processes through which rules are established for and applied to societal domains altered. Thus democracy needs to be refashioned not only to accommodate an emergent transscalar circumstance, but also to address an accompanying different form of regulatory apparatus.

At a previous historical juncture when social space centered on the country unit, regulatory processes correspondingly centered on the state which governed that realm. Each country had its own more or less unitary, centralized, territorial, bureaucratic public authority apparatus with executive, legislative, and judiciary arms. States in this earlier time were moreover institutionally discrete, intersecting only through diplomatic services and occasional meetings between heads of government. Given that societal governance was in the period to the third quarter of the twentieth century enacted more or less exclusively through states, the situation could suitably be characterized as "statist."

Over recent decades, however, processes of formulating, implementing, adjusting, and enforcing societal rules have been shifting from a statist to a polycentric mode. Governance of public affairs now occurs through many institutional sites that are complexly interconnected through dense policy networks. To elabo-

22. See e.g., Re-imagining Political Community: Studies in Cosmopolitan Democracy (Daniele Archibugi et al. eds., Polity Press 1998); Colin Hines, Localization: A Global ManiFESTO (2001). 
rate, statist and polycentric patterns of societal regulation can be differentiated in six main ways.

First, as already indicated, statist governance focused geographically on the country unit, whereas polycentric regulation relates to transscalar spaces. Statism is concerned with governing countries and relations between countries. Polycentrism includes the regulation of country domains, but also treats local, regional, and global spheres as sites of governance in their own right. Thus, for example, under polycentrism policies regarding local environmental concerns, regional investment strategies, and global communications networks are not reduced to questions of "national interest." Instead, public policy acquires a transscalar logic where local, national, regional, and global dimensions are interconnected but also distinct from one another.

Second, as the name suggests, statism almost exclusively involved a single type of regulatory actor (that is, the territorial nation-state), whereas polycentric governance transpires through various kinds of actors. To be sure, national governments remain key nodes in contemporary polycentric governance networks. The end of statism does not entail the end of the state. However, polycentric regulation involves in addition local governments, regional institutions, and global agencies playing their own active roles. Although these substate and suprastate governance bodies are often heavily influenced by states, they also exercise notable degrees of autonomy from national governments. Indeed, many provincial authorities now maintain their own deputations abroad, outside the diplomatic service of the nation-state. ${ }^{23}$ Morcover, "translocal" bodies such as United Cities and Local Governments (UCLG) directly connect substate authorities from multiple countries, without the intermediation of states. Similarly, the European Union (EU) has its own representation in over a hundred countries and maintains direct relations with other regional bodies such as the Gulf Cooperation Council (GCC) and the Southern Common Market (MERCOSUR). Such interregionalism could become a major channel of governance in future. ${ }^{24}$ For their part the main global governance agencies have seen their staffs grow from small secretariats into substantial bureaucracies. In addition, United Nations agencies and multilateral fi-

23. Brian Hocking, Localizing Foreign Policy: Non-Central Governments and Multilayered Diplomacy (1993); Earl Howard Fry, Substate Governance, in Encyclopedia of GlobaliZATION supra note 21, at 1099-1102.

24. See Interregionalism and International Relations: A Stepping Stone to Global Governance (Heiner Hänggi et al. eds., 2005). 
nancial institutions have in recent decades developed their own networks of representative offices around the world.

Further diversification in the types of regulatory actors has occurred with considerable privatization of contemporary governance. ${ }^{25}$ Whereas statist regulation was performed more or less exclusively through public-sector bodies, polycentric governance also transpires through many private regulatory mechanisms, as well as other institutions that combine public and private elements. Conceptions inherited from statist times tend to assume that societal regulation occurs by definition through public-sector agencies; yet business consortia and civil society associations can also construct and administer governance arrangements. The many examples of private regulatory arrangements include the Forestry Stewardship Council (FSC, to promote ecologically sustainable logging), schemes for corporate social and environmental responsibility (CSER), the International Accounting Standards Board (IASB, to improve and harmonize modes of financial reporting), bond-rating agencies (to set standards for access to commercial credit markets), and the International Fair Trade Association (IFAT, to advance the position of poor producers in global commerce). Private organizations can undertake functions of societal governance either on their own or in conjunction with public-sector bodies. Examples of public-private hybrid institutions include the Internet Corporation for Assigned Names and Numbers (ICANN) and the Global Fund to Fight AIDS, Tuberculosis, and Malaria. ${ }^{26}$ Like other trends identified in the present analysis, the privatization of societal governance is not completely new. For instance, traders created a lex mercatoria that provided codes of conduct for long-distance commerce in medieval Europe, ${ }^{27}$ and the Dutch and English East India companies predated their respective states as colonial administrators in Asia. These earlier instances duly noted, however, the rise of private regulation in contemporary governance is strikingly wide-ranging.

A third major contrast between statism and polycentrism relates to the nature of the state as a regulatory actor. Not only has polycentrism involved the growth of multiple sites of societal governance alongside states, but states themselves have

25. See The Emergence of Private Authority in Global Governance (Rodney Brice Hall \& Thomas J. Biersteker eds., 2003); Private Organizations in Global Politics (Karsten Ronit \& Volker Schneider eds., 2000).

26. See Benedicte Bull \& Desmond McNeill, Development Issues in Global Governance: Market Multilateralism and Private-Public Partnerships (2007).

27. A. Claire Cutler, Private Power and Global Authority: Transnational Merchant Law in the Global Political Economy 108-09 (2003). 
tended to disaggregate into multiple relatively autonomous policy decision points. ${ }^{28}$ Today justice ministries, environment ministries, finance ministries, employment ministries, foreign ministries, and more do not always operate together as one cohesive state unit and may in fact move in contradictory directions. Moreover, significant transgovernmental networks have developed that interlink functionally equivalent ministries from multiple countries. Whereas under statism only foreign offices maintained permanent direct ties with other states, under polycentrism any government department may have its own "international relations." Indeed, in many cases senior national civil servants thereby acquire closer connections with their counterparts in other states than with colleagues in other ministries within their own state.

Fourth, in consequence of the second and third developments just noted, the transition from statism to polycentrism involves a shift from more centralized to more diffuse construction of public policy. Under statism, policy decisions generally emanated from apex institutions of the country government, namely, the national cabinet, the national parliament, and national high courts. It was therefore relatively straightforward to identify the authorities who were responsible for a given policy development and also relatively easy to coordinate policy responses to a given issue. In contrast, under polycentrism the formulation, implementation, adjustment, and enforcement of societal rules occur in a far more dispersed fashion. Instead of having a clear hub for decision-taking and policy coordination like the state, polycentric governance is spread across multiple and diverse institutions and networks of institutions.

For instance, policy regarding the debt crisis of low-income countries has involved formal intergovernmental agencies like the International Monetary Fund (IMF) and the World Bank, informal transgovernmental relations through the Group of Eight (G8), coordinated bilateral negotiations under the auspices of the Paris Club, arrangements among private banks through the London Club, initiatives by nation-states individually, and actions by local governments (for example, to administer debt relief monies for public education and primary health care). Similarly, policy on corruption has developed through intergovernmental bodies like the Organisation for Economic Cooperation and Development (OECD), transgovernmental arrangements like the Global Organization of Parliamentarians Against Corruption (GOPAC), regional measures through the Organization of American

28. Anne-Marie Slaughter, A New World Order (2004); Kal Raustiala, The Architecture of International Cooperation: Transgovernmental Networks and the Future of International Law, $43 \mathrm{~V}_{\mathrm{A}}$. J. of INT'L L. 1, 2-3 (2002). 
States (OAS) and the Council of Europe, national legislation like the U.S. Foreign Corrupt Practices Act, private rules like the Transparency International (TI) Business Principles for Countering Bribery, and multistakeholder constructions like the Extractive Industries Transparency Initiative (EITI). In such situations of dispersed regulation it can often be difficult to determine locations of decision (and corresponding accountability) and coordinate policy actions. One commentator has spoken in this light (albeit with some hyperbole) of a "nobody-in-charge society."

Fifth (and exacerbating the difficulties of accountability and coordination), polycentric governance frequently involves overlapping jurisdictions, in contrast to the distinct and neatly separated country jurisdictions that marked the statist mode of governance. For example, trade in a particular item might be covered by rules of the WTO globally, a host of customs unions and common markets regionally, state legislation nationally, rules associated with special economic zones locally, and fair trade schemes privately. It can be problematic to reconcile different parts of a polycentric governance regime. Indeed, stakeholders may focus their lobbying efforts on different institutions, depending on where the groups expect to get the most receptive hearing and exert the greatest influence. In this vein, for instance, human rights campaigners might variously appeal to the United Nations Human Rights Council, to regional human rights regimes, to national constitutions, to local governments, or, in the private sector, to relevant CSER schemes. With overlapping jurisdictions of this kind, politics in respect of polycentric governance apparatuses can become quite untidy.

Sixth, and following from the preceding points, the shift from statism to polycentrism involves a move from sovereign to post-sovereign governance. By the principle of sovereignty, a single entity asserts absolute, supreme, comprehensive, exclusive regulatory control over a given jurisdiction. In this vein a national government could, under the statist mode of governance, claim unqualified, unilateral, all-encompassing, sole authority in respect of the country to which it was assigned. However, no agency can aspire even to approximate such predominance in conditions of polycentric regulation. As indicated above, this emergent mode of governance involves multiple kinds of disaggregated actors with dispersed authority in respect of overlapping jurisdictions. Sovereignty cannot fit in the polycentric mold. True, many national governments still appeal to traditional international law to reaffirm the principle of state sovereignty. However, they deploy a discourse of sovereignty more to bolster their position within polycentric networks, rather

29. Harlan Cleveland, Coming Soon: The Nobody-in-Charge Society, The Futurist, Sept.-Oct. 2000 , at 52. 
than actually to practice what has become an utterly unfeasible principle. In polycentric governance, sovereignty in the sense of the single and final say over a given jurisdiction is not available to any actor, whether state or other.

To recapitulate, contemporary history has witnessed a changing framework of governance marked by shifts: (a) from country units to transscalar spaces; (b) from state actors to multiple types of regulatory institutions; (c) from unitary to disaggregated states; (d) from centralized to dispersed decision-taking; (e) from discrete to overlapping jurisdictions; and (f) from sovereignty to divided authority. Increasingly since the 1990s analysts have grappled to find a suitable name for this post-statist condition. Suggested labels have included "plurilateralism," "polylateralism," "networked governance," "complex multilateralism," "empire," "new medievalism," "global issues networks," "cosmocracy," "mobius-web governance," "complex sovereignty," and "disaggregated world order." ${ }^{30}$ For all the variety of this vocabulary, however, the authors in question have each been broadly describing a circumstance of transscalar, multi-actor, diffuse, crosscutting, postsovereign regulation.

The terminology preferred here to designate the altered mode of governance is "polycentrism." This descriptor conveniently requires only a single word and suitably connotes a situation of complex regulatory networks. Moreover, the word polycentrism spans different scales without prioritizing any of them, in the way that a globalist tenor could easily be read into the term "cosmocracy." In addition, the notion of polycentrism avoids the potentially confusing disparate associations that attach to the word "empire." Critics might object that the term polycentrism still places too much stress on "centers" in what is a highly decentered circumstance. Yet contemporary governance networks do have nodes, and indeed some of those nodes (like the U.S. government or the European Union) can loom quite

30. Phillip G. Cerny, Plurilateralism: Structural Differentiation and Functional Conflict in the Post-Cold War World Order, 22 Millennium 27 (Spring 1993); Geoffrey Wiseman, "Polylateralism" and New Modes of Global Dialogue (Leicester Diplomatic Studies Programme, Discussion Paper No. 59, 1999); Wolfgang H. Reinicke, The Other World Wide Web: Global Public Policy Networks, 117 Foreign Poly 44 (Winter 1999-2000); Robert O'Brien et al., Contesting Global Governance: Multilateral Economic Institutions and Global Social Movements (2000); Michael Hardt \& Antonio Negri, Empire (2000); Jörg Friedrichs, The Meaning of New Medievalism, 7 Eur. J. INt'L Rel 475 (2001); Jean François Rischard, Global lssues Networks: Desperate Times Deserve Innovative Measutes, Washington Quarterly, Winter 2003, at 17. John Keane, Global Civil Society? (2003); James Nathan Rosenau, Distant Proximities: Dynamics beyond Globalization (2003); Edgar Grande \& Louis Pauly, Complex Sovereignty: Reconstituting Political Authority in the Twenty-First Century (2004); Anne-Marie Slaughter, A New World Order (2004). 
large. The label polycentrism well conveys a condition of multiple, dispersed, and complexly interconnected centers, as opposed to no centers at all.

Like the shift in the deeper structure of social geography from countries to transscalar spaces, the associated shift in the underlying mode of governance from statism to polycentrism calls for a fundamental reconstruction of democracy. At a time when societal regulation transpired more or less wholly and solely through the state, "rule by the people" was suitably pursued mainly in relation to national government. However, as governance now occurs through polycentric networks, democracy needs to operate in respect of that altered regulatory apparatus. A citizen's concern is no longer so much "what has my state done about this problem?" as it is "how has the relevant polycentric governance network affected me and my community?"

\section{Collective Identity: From Nationalism to Pluralism}

Yet who comprises "my community" in contemporary society marked by transscalar geography and polycentric governance? It was affirmed at the outset of this argument that democracy relates to an intersection of space, regime, and collective identity. Tight interconnections among these three core dimensions of societal organization imply that changes in one aspect tend to be accompanied by, and encouraged through, changes in the other two. Democracy would therefore need to be reconstructed not only in relation to a reconfigured geography and a restructured regulatory apparatus, but also in relation to concurrent changes in patterns of collective identity. Such changes have indeed been occurring.

Matters of collective identity go to the heart of affective aspects of the demos. Where do persons perceive their circles of belonging to lie? On what basis do individuals identify the fellow beings with whom they share a common life and destiny? More particularly, who is this "we" in a society marked by transscalar geography and polycentric governance? How do people perceive "the community" whose general interests democracy is meant to secure in the emergent new circumstances?

In the reigning formula of a preceding era, the form of collective identity that corresponded with country-based geography and state-based governance was the nation. The people, the public, the "we" were framed in terms of a national community. The demos was the Argentine nation, the Burmese nation, the Ethiopian nation, the Polish nation, etc. The public interest was generally understood in 
terms of the "national interest." In this situation the principle of democracy translated into the practice of national self-determination.

Although the precise character of a modern nation has tended to remain notoriously elusive, constructions of national identity generally combine four features. First, a nation encompasses a large population, in which most persons will never have face-to-face contact with one another. To this extent the bonds of the nation must be forged in good part symbolically as an "imagined community."31 Second, a nation is defined by its association with, on the one hand, a given country as the putative territorial homeland and, on the other hand, a state that rules (or, if it does not yet exist, should rule) that domain. Third, a national identity rests on claims of unique features (e.g., artifacts, faith, history, language, and rituals) that purportedly set the group in question apart from others. Fourth, a national identity carries priority entitlements (e.g., to citizenship, domicile, legal protection, and welfare guarantees) that others obtain only secondarily and discretionarily, if at all.

Much as countries remain an important facet of transscalar geography and states remain an important aspect of polycentric governance, so nations remain an important dimension of collective identity in contemporary society. Thus prospective reconstructions of democracy must still give important consideration to national identities. However, much as countries have gone from being the whole to a part of social geography, and much as states have gone from being the whole to a part of societal governance, so nations have gone from being the whole to a part of collective identity. Where the nation previously was the demos, now it is one of several bases of political community. The underlying structure of collective identity has in this sense shifted from a nationalist to a plural pattern.

The plural character of contemporary constructions of collective identity differs from the preceding nationalist orientation in three key ways. First, in a society marked by plural identities, persons often hold collective attachments to other territorial domains besides legally recognized countries. There is a multiplication of territorial identities within as well as beyond established country units. Second, in the emergent situation of plural identities persons are far more inclined than before to construct their notions of belonging in nonterritorial as well as territorial terms, for example, in respect of faith, race, or sexuality. In such cases distinctions between "peoples" have no particular correspondence to boundaries between countries. Third, the emergent condition of plural identity is marked by pervasive hybridity, where populations as well as the individuals that comprise them host

31. See e.g., Benedict Anderson, Imagined Communities: Reflections on the Origin and Spread of Nationalism (rev. ed. 1991). 
several collective identities in complex combinations. In these cases even the individual person does not slip neatly and consistently into one clear identity category, but rather has multiple attachments whose relative priority may shift depending on the context at hand.

Regarding the first of these three broad distinguishing features in more detail, plural constructions of collective identity involve concurrent community attachments across several territorial domains. Much as contemporary social space combines several scales at once, and much as contemporary societal governance blends several jurisdictions at once, so contemporary approaches to social solidarity mix several geographical spheres at once. Whereas the older structure of nationalism connected collective identity more or less exclusively to a person's country, today many nation-like groupings attach in addition to both smaller and larger territorial realms.

For example, in tandem with the localization of geography and governance, the contemporary pluralization of identity is evidenced inter alia in so-called ethnonationalist revivals across the world. ${ }^{32}$ The scores of cases include Flemish and Walloon assertions in Belgium, autonomy strivings in Southern Sudan, and Tamil separatism in Sri Lanka. Similarly, movements of indigenous peoples across the different continents have also sought recognition and autonomy in relation to territorial homelands that lie outside established countries and states. ${ }^{33}$ Some aboriginal groups have adopted orthodox discourse by calling themselves "first nations," but these movements often aspire to an alternative type of community. For example, some indigenous peoples of Amazonia have invoked a discourse of "florestania" in preference to that of "citizenship," in order to convey their alternative, more ecologically centered understanding of rights and responsibilities in a polity. ${ }^{34}$

Contemporary history has in addition brought other reconstructions of territorially based communities on scales larger than established countries, namely, with respect to regional and global fields. A regionalist turn in collective identities has manifested itself, for instance, in affirmations of so-called "Asian values," in notions of a continental Bolivaran revolution in Latin America, and in the promotion of European citizenship in relation to the European Union. Meanwhile global-scale constructions of national communities have developed in respect of

32. See e.g., Walker Connor, Ethnonationalism: The Quest for Understanding (1994); Michael Keating \& J. McGarry, Minority Nationalism and the Changing International Order (2001); Ethno-Nationalism and Emerging World (Dis)Order (Gurnam Singh ed., 2002).

33. See S. James Anaya, Indigenous Peoples in International Law (1996).

34. Interview with the Grupo de Trabalho Amazônico (Amazon Working Group), in Manaus, Braz. (Aug. 17, 2005). 
diasporas. ${ }^{35}$ Prominent examples of these globalized nations include transplanetary solidarities of Africans, Chinese, Kurds, and Palestinians. In the case of diasporas, collective solidarity is based on affective attachment to a territorial homeland that many members of the national group in question do not actually inhabit and indeed may never even visit.

Along with this multiplication of territorial solidarities, the contemporary pluralization of collective identities has also involved a proliferation of nonterritorial group attachments. In these situations individuals construct their sense of community around aspects of their being that are not defined by territorial locations or limited by territorial borders. For example, co-religionists dispersed across the planet may experience a sense of belonging that is rooted in their joint faith. Similarly, persons from around the world who practice the same vocation may forge a collective identity as academics, managers, musicians, peasants, or street vendors. ${ }^{36} \mathrm{La}$ Francophonie links people associated with French language and culture worldwide, while official and non-official Commonwealth agencies draw together an Anglophone equivalent. Other globally spread groups create common cause around a shared experience of social subordination, say, as disabled persons, outcastes, people of color, sexual minorities, slum dwellers, or women. ${ }^{37}$ Occasionally, exponents of nonterritorial solidarities co-opt the language of nationhood in self-descriptions as, for instance, the "Nation of Islam" or the "Queer Nation." However, this subversion of conventional meanings serves to emphasize that alternative bases of collective identity are available.

Still another nonterritorial construction of collective identity in the emergent plural circumstance makes no group distinctions within humanity and instead identifies the species homo sapiens itself as a basis for social belonging and solidarity. Such a universalist conception of "the people" informs ideas of "human" rights and practices of "humanitarian" assistance and intervention that have obtained much greater currency over recent decades. Appeals to universal human solidarity have also gained more concrete significance in contemporary history given

35. E.g., Robin Cohen, Global Diasporas: An Introduction (1997).

36. Annette Aurélie Desmarais, La Vía Campesina: Globalization and the Power of Peasants (2007); Kees van der Pijl, Transnational Classes and International Relations (1998).

37. See The Global Emergence of Gay and Lesbian Politics: National Imprints of a Worldwide Movement (Barry D. Adam et al. eds., 1999); Peggy Antrobus, The Global Women's Movement: Origins, Issues and Strategies (2004); Eva-Maria Hardtman, "Our Fury Is Burning": Local Practice and Global Connections in the Dalit Movement (2003); Sheela Patel et al., Squatting on the Global Highway: Community Exchanges for Urban Transformation, in Global Citizen Action (Michael Edwards \& John Gaventa eds., 2001). 
specters of global disease, global ecological changes, global economic crisis, and global war. In line with this trend, talk of and literature on cosmopolitanism, global citizenship, global civil society, and global public goods have burgeoned since the mid-1990s. ${ }^{38}$

In sum, the pluralization of collective identities in contemporary history has involved a multiplication of territorial and nonterritorial frameworks of social solidarity. The situation is the more complex inasmuch as different patterns of attachment often converge on the same persons and places, with the result that contemporary collective identities obtain a pronounced hybrid character. ${ }^{39}$ In this vein, for example, unprecedented numbers of individuals today espouse two or more national identities at the same time, a situation that many states have acknowledged with legal reforms to allow dual citizenship. In addition, with hybridity a person may experience concurrent bonds of common destiny with national, subnational, and supranational territorial communities, and possibly also nonterritorial solidarities connected with class, gender, and religion. Likewise, any given location in contemporary society tends to host multiple collective identities in combination. This hybridity is particularly manifest in major urban centers, where street life can interweave large numbers of highly diverse cultural strands. Yet even remote rural outposts today tend to house intersections of several collective attachments, say, in relation to an indigenous life-world, national citizenship, peasant solidarity, religious affiliation, and humanity as a whole.

Like shifts to transscalar spaces and polycentric regulation, the pluralization of collective identities requires fundamental adjustments to constructions of democratic practice. These reconfigured frames of social solidarity radically alter the character of "the people" in "rule by the people." Under conditions of old-style nationalism the demos had a singular character (namely, that of the national population attached to a given country and state), and humanity could be fairly neatly divided into relatively discrete communities. In contrast, politics today must accommodate multiple kinds of "people." Moreover, those diverse communities are often seeking self-determination at the same time, in the same place, and through overlapping populations.

The one-dimensional nationalist matrix of old is therefore sorely inadequate

38. See, e.g., April Carter, The Political Theory of Global Citizenship (2001); Mary Kaldor, Global Civil Society: An Answer to War (Polity Press 2003); Global Public Goods: International Cooperation in the 2ist Century (Inge Kaul et al. eds., 1999); Thomas W. Pogge, World Poverty and Human Rights: Cosmopolitan Responsibilities and Reforms (2002).

39. See Jan Nederveen Pieterse, Globalization and Culture: Global Mélange (2004). 
for democratic practice in the twenty-first century. A nationalist world can only be sustained today by marginalizing and suppressing the various other collective identities that persons find meaningful in combination with-or sometimes even instead of-their attachment to a country-state-nation. In the post-nationalist circumstance that now prevails, "rule by the people" must be reconstructed to address plural communities steeped in hybridity.

To round off this second stage of the argument, the preceding account of contemporary social change suggests a need for comprehensive reconsideration of democratic practice. Orthodox models of democracy inherited from an earlier era assume a society of country-based geography, state-based governance, and nationbased community. Yet historical developments have overtaken each of these three presumptions. Countries, states, and nations remain highly important in contemporary society, to be sure, but they no longer stand alone, having been absorbed into more multidimensional forms of space, regulation, and identity. To work effectively, democracy must be reconstructed to address these emergent interrelated conditions of transscalar geography, polycentric governance, and plural community.

\section{Whither Democracy?}

Hence the challenge at hand is to give more specific shape to this general prescription: how could the required new mode of democracy operate? Of course the present summary reflection cannot work through all of the complexities involved. Moreover, it would be incongruous to impose a precise blueprint with purported universal applicability, given the exponential variability generated through combinations of multiple spaces, multiple regulatory agencies, and multiple collective identities. Instead, the following discussion elaborates several suggested broad starting points for a longer-term project of reconstructing democracy in an altered social order. Later work can then further explore both the conceptual issues and the diverse ways that the broad principles could be applied in different concrete situations..$^{40}$

As summarized at the outset of this essay, the general strategy to reinvent democracy proposed here involves five core tasks, to be undertaken concurrently. One crucial step is to reconceptualize the problem of democracy, as is attempted in the present analysis and other writings. A second vital exercise is to refashion civic education so that all people, including marginalized circles in particular, be-

40. Grant support has been obtained to convene a series of global workshops in 2008-2010 to explore these questions in more detail. 
come empowered to act on conditions of transscalar geography, polycentric governance, and plural community. A third indispensable move is to redesign processes of public accountability so that they address the whole of polycentric governance networks and answer to all aspects of plural communities. A fourth requisite is to effect progressive structural redistributions of resources and power (among classes, countries, cultures, genders, races, etc.) in order that all stakeholders in contemporary public policy issues have more equal opportunities of political participation and control. A fifth key challenge is to nurture ethics of what might be called "pluriversality," a political-philosophical outlook that enables diverse collective identities to make decisions regarding their overlapping destinies with mutually enhancing intercultural communication and negotiation. These five tasks are elaborated in turn below.

These efforts are the more urgent since politics today provides shaky foundations for all five cornerstones of the proposed reconstruction of democracy. Reigning conceptions of democracy are still on the whole formulated with limited if any regard to realities beyond countries, states, and nations. Available civic education generally leaves citizens largely ignorant of emergent new patterns of geography, governance, and community. Existing policymaking processes allow many if not most agencies in polycentric regulatory networks to escape meaningful public accountability. Prevailing (mal)distributions of resources and power create enormous inequalities that inhibit substantive democracy. And dominant political practices are little accomplished in arts of intercultural recognition.

\section{A. Reconceptualization}

Given that this entire article addresses challenges of rethinking democracy, the issue of reconceptualization requires little elaboration under a specific subheading here. However, it is suitable at this juncture to consolidate three fundamental adjustments to ontological and methodological starting points that underpin the proposed reconfigured ideas and practices of democracy. Contemporary reconstructions of "rule by the people" require alterations to several core assumptions about the nature of social relations. Democracy cannot be successfully rebuilt in a transformed situation if the would-be builders have not grasped the transformations and reframed their knowledge accordingly. As already intimated in the discussion so far, 
three key reorientations at the heart of a rethought democracy involve different understandings of space, governance, and community.

Regarding geography it is necessary when renovating democracy in respect of contemporary society to abandon the ontological and methodological territorialism that has previously underpinned mainstream knowledge of society and politics. ${ }^{41}$ Territorialist premises assume that social relations transpire spatially in neatly bounded plots of the earth's surface. In this old mindset, human society is conceived to divide into discrete parcels of territory (usually countries) that are separated from one another by borders plotted on a three-dimensional graph of latitude, longitude, and altitude. With regard to democracy more specifically, territorialist assumptions correspondingly dictate that "rule by the people" should be constructed in relation to territorial (usually country) units.

Yet, as seen earlier, territorialist presumptions are unsustainable in respect of emergent realities of transscalar geography. "The public" that is due selfdetermination often cannot be plotted on conventional territorial maps. In contemporary social relations local, country, regional, and global domains continually intersect and merge. As a result, territorial units only partly-and sometimes only remotely-correspond to the spatial patterns of actual exchanges and interdependencies in society. Indeed, today many social relations are substantially "supraterritorial" in the sense that connections among people flow across transplanetary spaces, largely unconstrained by territorial locations, territorial distances, and territorial borders. Mobile telephony, the internet, climate change, and electronic finance illustrate high degrees of supraterritoriality. ${ }^{42}$

Hence reconstructions of democracy for contemporary society need to build on a fundamentally different understanding of social geography. "The public" today inhabits multiple, overlapping, and in some respects substantially supraterritorial domains. The "where" of democracy needs to be relocated to transscalar spaces; however, such reconstruction is difficult so long as political imaginations are encumbered with obsolete territorialist assumptions.

Likewise, contemporary reconstructions of democracy require an abandonment of ontological and methodological statism in understandings of governance. Statist mindsets inherited from earlier times assume that societal regulation by definition occurs wholly and solely through national governments. Such pre-

41. See William E. Connolly, Territoriality and Democracy, 20 Millennium 463 (1991); John Gerard Ruggie, Territoriality and Beyond: Problematizing Modernity in International Relations, 47 InT'L Org. 139 (1993).

42. See Scholte, supra note 14, at 60-84. 
sumptions were viable - and also politically helpful in struggles for democracywhen, as previously, governance was enacted more or less entirely through states.

Yet, as indicated earlier, societal regulation today increasingly transpires through polycentric networks that involve much more than states. When applied to this altered context, statist lenses bring only part of the scene into focus and leave the wearer blind to the rest. In today's circumstances, strivings for democracy that concentrate only on the state cannot generate genuine "rule by the people," since so much governance is taking place elsewhere. Whereas statist thinking once promoted democracy, it now can stand in the way.

On a third front, contemporary reconceptualizations of democracy require the abandonment of ontological and methodological nationalism in understandings of political community. Assumptions inherited from a previous era maintain that national identity provides the overriding basis for collective belonging and social solidarity. Older conceptions of democracy therefore equated "rule by the people" with national self-determination.

Yet, as indicated earlier, collective identity - and hence the nature of the demos - has now acquired a plural and hybrid character. In contemporary politics, people experience multiple and overlapping group attachments. As a result, collective interests are not always or only defined in terms of a national community. In these circumstances a methodologically nationalist mindset misses much of the affective character of actual politics today. Indeed, that oversight makes it more difficult for non-national solidarities to be recognized and nurtured.

As ever, therefore, knowledge is part of - and shapes the possibilities forpractice. The ways that one thinks of democracy frame the ways that one does democracy. If the underlying premises of a strategy for democracy are flawed, then the entire exercise is compromised. In this way social knowledge rooted in territorialist, statist, and nationalist assumptions obstructs the realization of democracy today. If veritable "rule by the people" is now to prevail in respect of, for example, governance of armed forces, climate change, financial markets, and infectious diseases, then the conceptual underpinnings of such endeavors need to shift towards notions of transscalar geography, polycentric governance, and plural community.

\section{B. Civic Education}

Such reconceptualization of democracy can be greatly advanced if processes of civic education make entire publics critically aware of the altered structures of space, regulation, and collective identity that shape contemporary society and pol- 
itics. People cannot perform democratic action in respect of transscalar domains, extract accountability from polycentric governance networks, or practice ethics of pluriversality if they have not learned to do so. Effective civic education is therefore crucial for a reconstructed democracy and requires far more attention than it at present receives.

Democratically empowering knowledge arguably comprises four components: information, insight, critique, and action. In one respect, then, civic education must make publics aware of relevant empirical details. Such information would include, for example: the functions, the modus operandi, and the impacts of relevant local, national, regional, and global regulatory institutions; the principles behind and histories of various social movements; and so on. Currently most people are at best only vaguely aware of many of the spaces, governance agencies, and cultural identities that shape contemporary society and politics.

Second, in addition to comprehensive relevant information, civic education must equip all citizens with conceptual tools that bring a manageable analytical order to what otherwise appears to be an overwhelming complexity of actions and circumstances. The sorts of understandings of space, governance, and community set out above are crucial in this regard. In addition, education in concepts such as caste, class, gender, and race can enable citizens to understand broader patterns of social relations, including entrenched arbitrary hierarchies that often undermine democratic equality.

Third, democratically empowering civic education must nurture critical faculties. In this way all members of a given public would have the ability and the confidence to question presented facts and to contemplate alternatives to received wisdom, especially when established accounts serve oppressive power. With underdeveloped critical thinking contemporary publics all too often react to undemocratic circumstances with passivity and resignation.

Fourth, civic education for effective democracy must gear knowledge to action, such that the acquired information, insights, and critical competences feed into and enable initiatives that place public participation and control at the heart of governance. Democracy needs more than sharp observers of events. A more fully educated democratic citizen is also able to assess the likely impacts and the viabilities of different tactics and strategies, and accordingly to select effective courses of action.

Democratically empowering civic education of this fourfold kind can be delivered through a number of channels, although none of them is at present adequately fulfilling its potentials. Political socialization begins largely in schools; hence the above vision of civic education would suitably inform curricula across 
the primary and secondary grades. Indeed, innovative schools and teachers have introduced important initiatives to raise children's awareness of the transscalar geography, polycentric governance, and plural communities that shape the twentyfirst century. Exercises in this direction include Model United Nations programs, virtual exchanges via internet with other schools worldwide, and explicit attention to cultural diversities within the school itself. Another experiment has seen visionary youth workers of the Vancouver-based Check Your Head project stimulate creative political learning with thousands of classroom visits across British Columbia. Yet such programs tend to be the exception. All too often core curricula of childhood education still reproduce an outdated ontological and methodological territorialism, statism, and nationalism. As a result pupils obtain little knowledge of social geography outside a country framework, societal governance outside a state framework, and social solidarity outside a nation framework.

Sadly, curricular reconstructions are frequently just as urgently required in tertiary education. Even many contemporary social studies degrees remain steeped in now obsolete conceptions of space, regulation, and community. Thus, for example, most economics programs still presume a world of countries, with an emphasis on gross national product, international trade, etc. Similarly, most comparative politics courses still presume states as the unit of comparison. Most anthropology and sociology textbooks still presume locality or country as the framework of culture and community. As a result of such outdated curricula, today's new generations of professional cadre are emerging from higher education insufficiently equipped to address the changing circumstances of public policy. More promisingly, a number of recent initiatives in interdisciplinary so-called "global studies" have challenged old assumptions. However, these new curricula thus far remain on the fringe, and care must be taken that global studies do not slip into a methodological globalism that overcompensates for the shortcomings of orthodox social enquiry by ignoring the continuing importance of countries, states, and nations.

In some cases student associations have taken re-education for new modes of democracy into their own hands. Inspiring examples in this regard include the U.K.-based People \& Planet initiative and the forward-thinking biennial International Student Festival in Trondheim (ISFiT). In addition, some so-called "popular universities" inter alia in Brazil and Sweden have included civic education components that equip in particular civil society activists for political engagement. That said, some offerings in popular universities, too, remain rooted in outdated territorialist, statist, and nationalist conceptions of society.

Outside of formal learning establishments, most people obtain most of their 
day-to-day civic education from the mass media. It might therefore be hoped that the written press, broadcast channels, the film industry, and websites could raise citizen awareness of transscalar geographies, polycentric governance networks, and plural communities. Some of these outlets have indeed done so, including in "entertaining" ways such as globally transmitted concerts and reflexive travelogues. Alternative sources of news and political analysis such as Indy Media, the openDemocracy website, and more localized initiatives such as the Prachadharm News Net in Thailand have made especially valuable contributions to innovative civic education. Yet the dominant mainstream mass media have generally given at best limited and superficial attention to transscalar interlinkages of different social arenas, to governance processes beyond the state, and to the increasingly plural and hybrid character of contemporary political communities. On the contrary, many if not most mass-circulation newspapers and mass-audience broadcasters today mainly peddle politically anaesthetizing consumerism that quells energies for democratic mobilization.

Many other civic education initiatives that can further a positive reconstruction of democracy in emergent new historical conditions have emanated from civil society quarters. Citizen advocacy groups such as nongovernmental organizations (NGOs) and various social movement associations have in this vein sponsored public learning events, provided public learning centers, and produced learning materials that are accessible to broad constituencies, including marginalized circles. In terms of learning events that address changing contexts for democratic politics, civil society groups have held lectures, symposia, colloquia, workshops, discussion groups, round tables, artistic performances, and road shows. The World Social Forum process with its various global, regional, national, and local meetings illustrates this pedagogy especially well. ${ }^{43}$ In terms of learning centers these advocacy associations have created documentation libraries, museum exhibits, and websites that raise public awareness of shifting circumstances. In terms of learning materials, civil society organizations have distributed leaflets, brochures, bulletins, newsletters, magazines, books, policy briefs, dossiers, training manuals, audio-visual productions, wall posters, cartoons, paintings, and sculptures. Such activities have made many citizens - and in particular many in subordinated positions-more conscious of and more confident to speak out on contemporary politics. That said, the resources available for such civil society initiatives are severely limited; hence the overall numbers of people thereby reached have remained relatively small. Moreover, many civil society associations tend to underplay ef-

43. World Social Forum: Challenging Empires (Jai Sen \& Peter Waterman eds., 2004). 
forts at grassroots civic education while directing their main attentions to more "glamorous" pursuits of lobbying the corridors of power.

In sum, then, much remains to be done regarding civic education for a reconstructed democracy. As seen above, a number of initiatives al ready undertaken in schools, universities, the mass media, and civil society suggest promising ways forward. However, these efforts need to be greatly expanded and to be drawn from the fringes to the heart of citizen learning.

\section{Institutional Accountability}

Although upgraded civic education is crucial to any contemporary reconstruction of democracy, informed and analytically equipped publics will remain disempowered to the extent that institutional processes are not available to hold governors accountable to the governed. Democracy entails among other things that rulers answer to the ruled for their ("the authorities") actions and omissions. In a previous era, the statist mode of governance eventually acquired various procedures to promote public accountability of national government. These practices included plebiscites with universal suffrage, parliamentary oversight, an autonomous judiciary, ombudspersons, mass media scrutiny, and civil society mobilization. The shift to a polycentric mode of governance requires a reinvention of these and other accountability mechanisms so that they address not only country-based nation-states, but also the wider transscalar, multi-actor, diffuse, crosscutting, postsovereign regulatory networks that now undertake societal regulation.

Accountable governance has four principal interrelated aspects: transparency, consultation, evaluation, and correction. ${ }^{44} \mathrm{~W}$ ith respect to transparency, democratic accountability requires that governors are visible to the governed from the start to the finish of any given policy action. In other words, all affected constituents must always be able to see what the affecting regulatory actor is doing and how. Without disclosure of such information the demos cannot effectively scrutinize governing institutions. To be sure, as noted earlier, temporary limitations on transparency may sometimes be justified on public interest grounds. However, the democratic norm prescribes immediate and complete disclosure to all concerned. ${ }^{45}$

44. See Civil Society and Accounta ble Global Governance (Jan Aart Scholte ed., forthcoming 2008); Monica Blagescu et al., Pathways to Accountability: The GaP Framework (2005); Alnoor Ebrahim \& Edward Weisband, Forging Global Accountabilities: Participation, Pluralism, and Ethics 1-24 (Alnoor Ebrahim \& Edward Weisband eds., 2007).

45. Burkart Holzner \& Leslie Holzner, Transparency in Global Change: The Vanguard of the Open Society (2006); Christopher Hood \& David Heald, Transparency: The Key to 
Polycentric governance processes are at present often far from adequately transparent to affected publics. In many cases citizens cannot easily discover what decisions are taken through these regulatory complexes and how. Particularly obscure are many transgovernmental networks and private regulatory mechanisms that barely show any public face. Tracking the activities of entities such as the Competition Policy Network, the Nuclear Suppliers Group, and Moody's Investor Service challenges even the most dogged investigative journalist. A number of intergovernmental agencies like the EU and the IMF have greatly improved their public disclosure practices over the past decade, usually only after prolonged pressure against reluctant bureaucracies. However, other suprastate bodies remain highly secretive, and even the most transparent intergovernmental organizations still withhold crucial information like the minutes of board meetings or the names and contact details of staff.

Next to transparency, consultation as a second core aspect of democratic accountability requires that governors explain intended actions to all affected people and adjust policy in the light of information, analysis, and preferences heard from those constituents. In other words, decision-taking is democratically accountable when the various stakeholders are thoroughly incorporated into the deliberations and have ample opportunities to shape the outcomes. This public participation should extend across the policy cycle, starting from the initial agenda formulation and continuing until the final retrospective report. The consultations may be direct (involving the affected persons themselves) or indirect (involving mediating parties such as parliaments and civil society associations). In the case of indirect engagement, the mediating agent should in its turn be accountable to those for whom it purports to speak.

Direct consultations of affected people are weak in much of contemporary polycentric governance. True, the leaders and legislators of most national and local governments are today elected by universal suffrage of qualified citizens. However, the circumstances of these plebiscites can be suspect in terms of voter manipulation and ballot fraud. Meanwhile, all but a handful of regional, global, and private regulatory agencies have no public consultations via plebiscite at all. The rare exceptions include the EU Parliament, with directly elected delegates since 1979, and ICANN, which had five of its board members selected through an online global poll in $2000 .{ }^{46}$ World federalists have proposed various designs of

Better Governance? (2006).

46. Hans Klein, The Feasibility of Global Democracy: Understanding ICANN's At-Large Elections, 3 J. of Pol'y, Reg., \& Strategy for Telecomm. Info. \& Media 333-45 (2001). 
popularly elected global parliaments, but there is at present little prospect that such speculations will bear concrete results in the foreseeable future. ${ }^{47}$

Even then, elected representative councils often have only partial, irregular, and superficial involvement in the decision-taking processes of polycentric governance. Sometimes a national government consults legislators regarding its policies in one or the other suprastate forum, but more generally such discussions are avoided. ${ }^{48}$ Indeed, many interstate treaties and many state agreements with regional and global regulatory agencies are not subject to parliamentary ratification. Likewise, transgovernmental networks generally operate through informal memoranda of understanding that are concluded without any reference to legislative bodies. Nor do popularly elected assemblies give much if any input to the workings of private regulatory mechanisms. In short, representative institutions are excluded from decision-taking processes in large parts of polycentric governance. One major step toward greater democracy could therefore be a reinvigoration of policy involvement by popular assemblies.

Gaps in consultations of affected publics through plebiscites and elected bodies are sometimes partly filled through exchanges between governance circles and relevant civil society associations. These citizen action groups can help, from outside political parties and parliaments, to channel the voices of various constituencies to policy institutions. Indeed, civil society activities can provide opportunities of participation for social circles, such as aboriginal peoples and women, that may get a limited hearing in party politics. The many examples of civil society initiatives include animal rights activists, anti-poverty movements, business forums, caste solidarity groups, clan and kinship mobilizations, consumer advocates, democracy promoters, citizen-based development cooperation actions, disabled persons alliances, environmental campaigns, ethnic lobbies, faith-based associations, human rights advocates, labor unions, local community groups, peace drives, peasant movements, philanthropic foundations, professional bodies, relief organizations, research institutes, sexual minorities' associations, women's networks, youth groups, and more. Many local, national, regional, and global governance agencies have now built consultations of civil society groups into their policy pro-

47. See George Monbiot, The Age of Consent: A Manifesto for a New World Order (2003); Richard Falk \& Andrew Strauss, Toward Global Parliament, 80 For. Aff. 212, 216-20 (2001).

48. See Robin Round, Who's Minding the Store? Legislator Oversight of the Bretton Woods Institutions (Halifax Initiative 2004), http://www.halifaxinitiative.org/updir/Legislator_Oversight _Executive_Summary_Recommendations.pdf. 
cesses. Some private regulatory arrangements like the FSC and a number of CSER schemes also incorporate inputs from civil society.

That said, consultations of civil society associations are limited or absent in many quarters of contemporary polycentric governance (including most transgovernmental networks, for example). Even where exchanges with civil society groups are firmly institutionalized, critics worry that the "consultation" can be largely ritualistic and effects little actual policy change. Moreover, civil society associations often lack adequate processes to ensure their own accountability to constituents. Recent initiatives such as the International Non-Governmental Organization Accountability Charter have begun to address this problem, ${ }^{49}$ but the matter still requires much more attention. Thus while civil society engagement could in principle make large democratizing contributions to polycentric governance, the potentials require much more development. ${ }^{50}$

With respect to the third dimension of democratically accountable policymaking, evaluation requires that the impacts of a governance institution on affected publics are subject to thorough monitoring and assessment. Some of the evaluation can come from within the agency itself, for example, through published annual reports and internal inquiries into one or another activity. As importantly, however, evaluation should also come from external parties, for example, through academic studies, civil society reports, judiciary proceedings, media investigations, officially commissioned panels, parliamentary reviews, and/or testimonies of the affected persons themselves. Through some combination of these various means, accountability entails an obligation to determine how affected circles have been affected. In democratically accountable governance, impacted persons have a right to know how well the impacting regulatory agency has complied with its policy decisions and how far it has or has not achieved the promised results. Stakeholders furthermore have a right to receive tenable explanations when outcomes have fallen short of expectations.

As with transparency and consultation, the record on evaluation in respect of polycentric governance has many gaps. Certain agencies have established special review bodies, like the Inspection Panel of the World Bank and the Independent Evaluation Office of the IMF; however, such mechanisms are the exception rather than the rule. In terms of scrutiny by outside parties, certain high-profile issues and

49. See International Non-Governmental Organisations Accountability Charter (2007), http:// www.ingoaccountabilitycharter.org/download/ingo-accountability-charter-eng.pdf.

50. See Scholte, supra note 7; Jan Aart Scholte, Civil Society and the Legitimation of Global Governance, 3 J. of Civ. Soc'y 305 (2007). 
scenarios have gained considerable attention. Examples include the 1984 Bhopal chemical plant disaster, the 1994 genocide in Rwanda, and the global financial crises of the late 1990s. However, many other significant issues with major consequences for substantial populations have passed for years with little evaluation of note. What media investigations are highlighting policies on slums? Which parliamentary committees are examining strategies to combat tropical diseases? How many civil society groups have attended to accounting practices such as transfer pricing? How often do undocumented workers obtain a public hearing regarding their experiences of prevailing policies on migration? Has any outside party systematically evaluated the workings of the Derivatives Policy Group or the Internet Engineering Task Force? In short, democratic accountability in polycentric governance requires that more watchdogs more thoroughly scrutinize more issues and more regulatory institutions of polycentric governance. Moreover, it would be helpful if more evaluations considered the overall public policy network that affects a given problem, rather than examining individual agencies separately.

Finally, with respect to correction, democratic accountability requires that governors provide the governed with redress in cases where policy has had harmful consequences. This compensation might take the form of apologies, policy changes, institutional reorganizations, staff reprimands and resignations, reparations, or even incarcerations. In a situation of public accountability, affected circles must be assured that governing institutions take responsibility for their errors and learn from their mistakes.

On this fourth dimension of democratic accountability, too, the record of emergent polycentric governance has generally been wanting. With poor transparency, limited consultation, and weak evaluation it is difficult to build up effective pressure to change failing policies. Poorly performing executives are less likely to apologize, let alone resign, when most of them are not subject to public (re-) election. Most of the suprastate agencies and transgovernmental networks that comprise polycentric regulatory arrangements cannot be taken to any court to extract compensation for damages. Thus polycentric governance as it is currently practiced leaves many openings for mistakes to go unpunished.

In sum, major efforts are needed to upgrade public accountability in polycentric governance across all four dimensions of transparency, consultation, evaluation, and correction. In pursuing these ends it is vital to consider which constituencies the accountability exercises are serving. To whom and for whom do the institutions become transparent? Who does and does not get consulted? Who does (and does not do) the evaluation? Who does and does not obtain redress? 
The limited accountability that is currently available generally addresses some parts of affected publics more than others. For example, residents of Europe and North America currently have disproportionate opportunities to obtain accountability from polycentric regulatory arrangements as compared with inhabitants of other continents. Likewise, managerial and professional circles with tertiary education, fluency in English, and access to the most advanced information and communication technologies have far better chances to access available accountability mechanisms than other social classes. A number of constituencies, like disabled persons, indigenous peoples, sexual minorities, and women, have few political channels (apart from a handful of generally poorly resourced civil society associations) that address their specific accountability needs. The need is therefore not only to create more possibilities to make polycentric governance answerable to affected publics, but also to make those opportunities more equally available to all stakeholders.

\section{Structural Redistribution}

As stressed throughout this discussion, the principle of equivalent possibilities for participation and control for all individuals and groups lies at the heart of substantive "rule by the people." Any reconstruction of democracy in respect of transscalar geography, polycentric governance, and plural community must therefore have concerns about promoting equal opportunity at the fore. This priority has already featured above in regard to the conceptualization of democracy (i.e., equality should lie at its core), the audiences for civic education initiatives (i.e., political learning should especially empower the marginalized), and the constituencies for accountability mechanisms (i.e., processes of disclosure, consultation, evaluation, and correction should especially address the disadvantaged). However, no amount of conceptual, pedagogic, and institutional steps to promote equality will bear sufficient democratic fruit if these efforts are not also accompanied by measures to create material conditions for effective political equality. Hence a fourth general task of rebuilding democracy in the context of contemporary social change is to make redistributions of resources that help to level opportunities for political action across the relevant public.

A need to redistribute material resources in order to secure veritable democracy was also realized at an earlier historical juncture in respect of national selfdetermination through territorial states. Talk of democracy in a context of country spaces, state institutions, and national populations rang hollow so long as deeply 
entrenched social hierarchies gave certain circles in society large inbuilt arbitrary advantages in shaping public policy. In this regard structural inequalities within countries on lines such as age, caste, class, culture, (dis)ability, gender, race, sexual orientation, and urban/rural divides had (and often continue to have) profoundly antidemocratic consequences. A sine qua non to counter these adverse effects was to institute measures, especially through the state, that would systematically reallocate resources within the country in order to create more equal opportunities across the whole of the national population. To this end most states from the late nineteenth century onwards developed policies that, to varying degrees, deliberately redirected flows of resources to less advantaged social circles such as the lowwaged, the landless, subordinated ethnic groups, women, children, and the elderly. Needless to say, these state-centered programs for democracy-enhancing social justice within countries have nowhere completed their course. Indeed, recent history has seen some material gaps widen again in many countries. Nevertheless, redistributive policies on matters such as education, employment, health, social security, and taxation have on the whole improved the material basis for democracy in country-state-nation contexts as compared with a century ago. Opportunities of political participation and control have generally become more equal in these settings.

However, as indicated earlier, emergent new configurations of social space, regulation, and collective identity are altering the shape of the public to which democracy and accompanying demands for equality apply. "The people" in respect of whom a more even distribution of resources is required now often resides across and beyond countries as well as within them. It is no longer enough in pursuing democracy for a state to effect progressive redistribution of resources within a nation inhabiting a country. Rather, it becomes a task for polycentric governance apparatuses to further material leveling within multiple and cross-cutting communities that exist across several scales of geography. In effect, the need is for structural redistribution of resources across humanity as a whole, so that greater equality is available no matter where the lines of the public might be drawn in respect of a particular policy question.

At present, world social hierarchies are if anything steeper and more deeply entrenched than those prevailing in countries. For one thing, resource gaps between countries are often substantially greater than material inequalities within countries. Examples include the (mal)distribution between rich and poor countries of finance capital, digital technologies, trade earnings, health care facilities, and ecological damage. Other structural inequalities within humanity as a whole fall on non- 
geographical lines. For instance, in regard to household income differentials, the global-scale Gini co-efficient is, at roughly 0.65 , far higher than the Gini coefficient of almost any country. ${ }^{51}$ Little research has examined material inequalities across humanity in relation to other social categories such as age, caste, culture, disability, gender, race, and sexual orientation; however, there is every indication that these gaps are also particularly wide. In respect of religion, for example, countries with Muslim majority populations account for a fifth of humanity but only 6 percent of world gross domestic product (GDP).$^{52}$ Meanwhile, although there are good grounds to castigate the state for historical neglect of disabled persons, no suprastate legal instrument at all specifically promoted their welfare until 2006, with the signature of the U.N. Convention for the Rights of Persons with Disabilities.

To be sure, a number of limited steps have been taken to enhance structural equality across humanity through a redistribution of world resources in progressive directions. For example, official development assistance (ODA) has transferred some GDP from high-income to low-income countries, although these sums have been small compared to the redistributions that could be effected through changes to the rules governing finance, investment, and trade. After lengthy campaigns for debt relief, wealthy creditors have finally cancelled various unsustainable loans that perversely saw large payments made from the poorest to the richest countries. In the sphere of private governance, fair trade schemes have grown over the past decade in a thus far still modest effort to raise the earnings of poor producers. Meanwhile, taking a lead from the French government, a handful of states have since 2006 levied a tax on air travel in order to generate funds for the provision of essential medicines to low-income countries. The rhetoric of global public policy now often mentions gender concerns, and certain targeted schemes for microfinance and girls' education have sought to improve the material position of women. Yet, even collectively, these steps have so far made but marginal inroads into structures of world inequality.

Various other proposals to further a progressive redistribution of world resources are on the table if the political forces could be mustered to get them implemented. For example, a marginal tax on foreign exchange transactions could

51. See Bob Sutcliffe, A More or Less Equal World? World Income Distribution in the 20th Century (Political Economy Research Institute, Working Paper No. 54, 2002). See generally Branco Milanovic, Worlds Apart: Measuring Global and International Inequality (2005).

52. WTO and Globalization: Challenges for Muslim Countries, Tehran, Iran (Dec. 3-4, 2006) (Conference organized jointly by the International Islamic University of Malaysia (IIUM), the Islamic Development Bank (IDB), the Islamic Chamber Research and Information Center (ICRIC) and the Tehran Chamber of Commerce, Industry and Mines). 
generate far larger revenues for economic development promotion than ODA. ${ }^{53} \mathrm{~A}$ small "bit tax" on electronic commerce and other internet communications could achieve the same..$^{54} \mathrm{~A}$ Global Clearing Union (GCU) would allow each country to import and export using its own currency at stable exchange rates with a global currency, thereby avoiding dependence on the monetary unit of a dominant state and unpredictable market fluctuations. ${ }^{55}$ The establishment of a Fair and Transparent Arbitration Procedure (FTAP) or a Sovereign Debt Restructuring Mechanism (SDRM) could prevent a recurrence of the debilitating poor country debt crises of the past quarter-century. ${ }^{56} \mathrm{~A}$ global tax on the profits of transborder companies could spread the benefits of these business operations more widely and counter the maldistributions that are enabled through offshore registration. A global anti-trust regime could counter the tendencies towards oligopoly in global capitalism. The widespread application of Creative Commons licenses and Open Source software would make global knowledge more equally available to all. ${ }^{57}$ Adoption of the principle of universal and unconditional basic income (UBI) would guarantee minimum material welfare for all. ${ }^{58}$

While world-scale redistribution is indispensable to any redemocratization of contemporary society, ambitious proposals of the kind just illustrated are not ready-made for immediate implementation. Each would require extended efforts of careful technical design. Likewise, campaigns to change prevailing global economic regimes in order to effect major reallocations of resources and power would need to overcome formidable opposition from currently dominant circles, including big capital in particular. However, the point of the present discussion is not to specify detailed policy strategies so much as to indicate that substantial redistributions are in principle possible and democratically necessary.

53. See Heikk Patomäki, Democratising Globalisation: The Leverage of the Tobin Tax 123-25 (2001); David Hillman et al., Taking the Next Step: Implementing a Currency Transaction Development Levy (2006), http://globalpolicy.igc.org/socecon/glotax/currtax/2006/12ctdl.pdf.

54. Caslon Analytics Taxation Guide, The Byte Tax, http://www.caslon.com.au/taxationguide2 .htm (last visited Feb. 28, 2008).

55. See Robert H. Wade, The Case for a Global Currency, Int'l Herald Trik., Aug. 4, 2006, at 6.

56. CIDSE-Caritas Internationalis, Sustainability and Justice: A Comprehensive Debt Workout for Poor Countries with an International Fair and Transparent Arbitration Process (FTAP) (2004), http:// www.begak wabega.com/documenti/development-debt.pdf.

57. See www.creativecommons.org; www.opensource.org.

58. See Basic Income Earth Network (BIEN), About Basic Income, http://www.etes.ucl.ac.be/ bien/BI/Definition_temp.htm (last visited Mar. 31, 2008). 


\section{E. Intercultural Recognition}

As affirmed throughout the present analysis, democracy rests on ideational as well as material conditions. In particular, constructions of the public-i.e., the "who" of democracy-emanate from political imaginations in tandem with concrete circumstances. Not surprisingly in this light, structural patterns of material inequalities often parallel hierarchies between dominant and subordinate identity groups. A democratization of contemporary society therefore requires that material redistribution is pursued in conjunction with politics of intercultural recognition that provide equivalent opportunities of voice to all communities.

As discussed earlier, notions of "the demos" that should enjoy self-determination have shifted in recent history in the direction of plural collective identities. However, inherited practices of democracy cater mainly to a single form of political community, that of the state-based nation. A fifth key aspect of reconstructing "rule by the people" today is therefore to nurture practices that ensure due recognition of and political arenas for the multiple communities that cohabit in today's polity. This task is particularly daunting given: (a) the sheer numbers of collective identities involved; (b) the complex overlaps and dense interconnections among these groupings; and (c) the significantly divergent life-worlds that are often associated with different cultural identities.

Regarding the first of these three problems, politics of recognition in a refashioned contemporary democracy are complicated by the multiplicity of political communities that need to be addressed. As indicated earlier, the numbers of national identities have grown with the rise of multiple substate and suprastate nations alongside national groupings that are associated with existing states. In addition, various nonterritorial identities have gained increased political importance. Genuinely democratic practices would need to provide adequate opportunities of voice for all dimensions of political affiliation and solidarity, without an a priori privilege to the state-based nation.

Regarding the second challenge, that of overlap, contemporary cultural politics are the more intricate given the increasingly hybrid character of identities and communities. The various groupings just described are generally densely intermingled in the same living spaces and cannot be parceled out to discrete selfgoverning territories in the way that old visions of national sovereignty prescribed. Instead, democratic instruments must now address the cohabitation of multiple communities within a single demos. Indeed, each individual citizen today tends to hold affinities with several collective identities and at different junctures gives 
greater emphasis to one or the other aspect of her/his political subjectivity. In a democracy worthy of that name today, hybrid political personalities need multiple channels for voice as their focus of collective self-determination shifts, say, from nationality to faith or from profession to gender.

Regarding the issue of knowledge diversity, the contemporary challenge of accommodating multiple collective identities is all the greater inasmuch as the different groupings tend to inhabit life-worlds that do not fully coincide and indeed may substantially diverge. Part of what forges a sense of affinity and solidarity in an identity group is a shared way of understanding. The persons concerned experience a community of meaning, perceiving the same things, employing the same vocabulary, embracing the same values. Veritable collective self-determination only prevails if it is pursued in terms that are culturally meaningful to those involved. If, as today, the polity in question houses multiple cultures, then democratic practices must cater to several life-worlds at once.

Particular complexities arise for democracy when groups that inhabit a common polity have knowledge systems that are markedly incommensurate. In these instances certain aspects of one life-world are not accessible for another: "outsiders" cannot see the same things, speak the same language, or hold the same values as "insiders." Strikingly divergent perspectives may exist, for instance, between persons holding different religious beliefs or between persons of different sexual orientations. These points of incommensurability may go to the heart of social relations, for example, with incompatible understandings of property, gender, and nature. Similarly, political cultures may diverge with fundamentally incompatible notions of rights, power, and legitimacy. Situations of incommensurable life-worlds present marked challenges for constructive political communication and negotiation. In particular, democracy must be designed so that cultural divergences do not prevent some sections of the public from having due opportunities of voice.

Interculturality-in terms of relations among multiple, hybrid and culturally divergent collective identities - is by no means new to contemporary society, of course. For example, the country-centered, state-centered, nation-centered politics of old frequently had to address a coexistence within the same territory, say, of multiple religious communities or of indigenous populations with colonizing peoples. Likewise, cross-border inter-national encounters often involved, and continue to involve, some testing questions of intercultural relations.

However, intercultural practices of the territorialist, statist, nationalist world often failed these tests. True, principles of state sovereignty and national selfdetermination secured considerable space for national communities to pursue de- 
mocracy. Moreover, codes of diplomacy facilitated intercultural communication and negotiation in respect of an international society of modern states. For the rest, however, intercultural politics of this earlier time were often marked by considerable violence. Indigenous peoples and other national communities that did not correspond to existing countries and states were frequently repressed. In addition, non-national affinities and solidarities on lines such as class, race, and sexuality tended to be systematically subordinated to national frameworks, if these other communities were recognized at all. Cultural politics were all too often marked by indifference to otherness and an aversion even to acknowledge, let alone explore, diverse life-worlds. Such attitudes arguably did much to fuel colonialism, homophobia, inter-faith hostilities, patriarchy, and racism. Exclusionary nationalism promoted the widespread criminalization of homosexuality in early modern Europe, for instance. ${ }^{59}$

The current transition to a world of more plural collective identities presents significant opportunities to reconstruct democracy around ethics of intercultural recognition. The proliferation of social spaces and regulatory institutions offers many more venues for the expression of multiple, hybrid, and diverse collective identities. It is also imperative that these possibilities be exploited. With transscalar geography, polycentric governance, and plural community, the coexistence and codependence of different "peoples" is becoming ever denser: culturally, ecologically, economically, geographically, politically, and psychologically. Constructive interculturality has become all the more urgent as old cushions of territorial distance and territorial borders have largely dissolved.

Alternative identity politics arguably must begin with the principle of intercultural recognition. Such a stance rejects identity politics marked by the denial, silencing, marginalization, exclusion, and suppression of otherness. Instead, a politics of recognition acknowledges and indeed emphasizes the diversity of modes of being and belonging within a single society. Strangeness is received with openness and indeed hospitality. Difference is tolerated and indeed embraced. The other is urged to speak and the self is indeed keen to listen.

Recent history shows some, if limited, progress toward such a democratizing politics of recognition. In such a spirit, for example, a number of states have in recent decades amended their constitutions to acknowledge the indigenous peoples of the respective countries (e.g., in Brazil, Canada, and Sweden) or to accord more local autonomy to substate nations (e.g., in Belgium, Iraq, and Spain). Simi-

59. See George L. Mosse, Nationalism and Sexuality: Respectability and Abnormal Sexuality in Modern Europe (1985). 
larly, various United Nations measures of the past thirty years have highlighted the distinctive existence and rights of women, people of color, indigenous groups, and disabled persons. In addition, a few representative assemblies such as the Indonesian legislature and the Parliament of the World Religions have designated seats for nonterritorial constituencies related to class or faith. A larger recent trend has, moreover, seen many governance agencies institutionalize policy consultations with civil society associations that give voice to diverse collective identities. Such citizen organizations include black advocacy groups, campaigns for rights of the disabled, faith-based bodies, and women's movements. Civil society circles have also created their own venues, such as the CIVICUS-Worldwide Alliance for Citizen Participation (since 1993) and the World Social Forum (since 2001), where a wide range of political communities are invited to speak.

On the whole, however, such initiatives for intercultural recognition have remained toward the fringes of contemporary democracy when they need to lie at the heart of a society marked by transscalar geography, polycentric governance, and plural community. Mainstream intercultural relations today all too often still rest on opposition, fear, and threat, particularly as seen in upsurges of xenophobic nationalism and discourses of a "clash of civilizations." Laudable democratizing initiatives to recognize diversity remain relatively marginal in current politics, where "representation" is still predominantly framed in terms of national identities and state-based nations more particularly. Thus, for example, when the opening line of the U.N. Charter says, "We the peoples....", it more specifically signals, in accordance with the name of the organization, "We the nations."

To promote a politics of more comprehensive and deeper intercultural recognition is not to eschew difficult questions of evaluative judgments in respect of cultural diversity. To acknowledge the relativity of norms is not to underwrite a relativism in which all value frameworks would be accorded equal value. The principle of recognition does not necessarily entail agreement with and endorsement of another life-world, let alone a readiness and intention to make it one's own. On the contrary, it can be that one life-world contains elements that are highly objectionable in another, and in such situations people may express their discords and in some cases even seek to persuade the other to pursue alternative ways. However, with a principle of intercultural recognition, the starting point is an acknowledgement of difference and a tolerance of incommensurable values, so long as those norms do not entail repressive violence. In a politics of intercultural

60. See generally Samuel P. Huntington, The Clash of Civilizations and the Remaking of World Order (1996). 
recognition, identity groups seek to understand one another in their own terms and to explore the potential gains (which are almost invariably available) of mutual learning and exchange.

As just indicated, the limit of the acceptable in these ethics of pluriversalitywhere multiple life-worlds peacefully cohabit in a single social arena-is set by arbitrary violence. No argument of cultural difference justifies the suppression of fundamental rights. Renovated democracy for a reconfigured society therefore arguably needs to transpose the principle of human rights from the country-statenation arena to the emergent transscalar-polycentric-plural framework. Such a process is already underway, with a proliferation of global and regional human rights instruments since 1945. However, human rights principles have not yet been fully embedded at the core of all regulatory mechanisms, including suprastate and private governance bodies in particular. To this end, for example, the work of the WTO and CSER schemes could be formally subordinated to the international covenants of human rights signed in 1966, in the way that legislation emanating from a modern state has been subordinated to a bill of rights in the country concerned. This final concrete suggestion for the contemporary reconstruction of democracy is one of the most important.

To wind up these various proposals, then, the preceding third step in this essay has sought to refashion democracy so that it might better suit emergent new patterns of geography, governance, and community. The outline scheme has encompassed five interlinked lines of action: conceptual, pedagogical, institutional, material, and cultural. In terms of knowledge construction, the suggested priority is to shift methodologies away from now obsolete assumptions of territorialist space, statist regulation, and nationalist identity. In terms of civic education, the suggested priority is (through schools, universities, mass media, and civil society) to generate democratically empowering knowledge of contemporary social changes and ways that those transformations might be shaped to positive ends. In terms of policymaking processes, the suggested priority is to enhance institutional accountability by developing procedures of transparency, consultation, evaluation, and correction in respect of all the agencies that comprise polycentric governance networks. In terms of political economy, the suggested priority is to effect redistributions of world resources in order to counter arbitrary structural inequalities. In terms of culture, the suggested priority is to nurture ethics of pluriversality that embrace practices of intercultural recognition, communication, and negotiation. As a whole, this program of action certainly presents a daunting challenge, but then democracy is always a tall order. 


\section{Conclusion}

This article has attempted to sketch a reconstruction of democracy that could reinvigorate "rule by the people" in a contemporary society that is increasingly organized in terms of transscalar (rather than country-based) geography, polycentric (rather than statist) governance, and plural (rather than nationalist) collective identity. The proposed fivefold renovation interweaves conceptual, educational, institutional, material, and cultural strands. As such the approach draws uponbut in the combination also differs from-cosmopolitan, multilateralist, Marxist, and poststructuralist theories. Moreover, the map plotted here has taken particular instruction from-and is intended to consolidate and advance- the thoughts and practices of citizen activists the world over who are striving to reinvent democracy in their everyday lives.

To be sure, it is one thing to write of alternatives and quite another to bring them into common practice. Strong forces would resist the kind of reconstructed democracy that has been outlined here. For one thing, territorialist, statist, and nationalist presumptions still exert a powerful grip on many political imaginations, thereby forming a major mental obstruction to sorely needed democratic renewal. Notions of the territorially bounded homeland, state sovereignty, and national self-determination continue to hold wide appeal, even if these principles have become inadequate and impracticable underpinnings for democracy. Yet vested interests among national politicians and state bureaucracies-including those of dominant countries in particular - are generally only too eager to reinforce these outdated ideas inasmuch as the concepts can still serve to bolster their power. Likewise, strong forces of big capital tend to oppose reconstructions of democracy that would (a) subject regionalized and globalized corporate activity to thorough public accountability and (b) distribute resources more evenly across society. Meanwhile, in the cultural sphere people in general have as yet limited aptitude for the kind of ethics of pluriversality promoted here. All too often identity politics still operate by drawing binary oppositions in which definitions of the self emerge from a differentiation, denigration, and exclusion of the other. Moreover, many western modernists tend to resist a reconstruction of democracy that casts critical scrutiny over their current cultural hegemony.

These significant difficulties duly noted, in other respects contemporary circumstances also offer notable opportunities to develop new directions in democratic practices. To begin with, many people are increasingly aware that reconfigurations of geography, governance, and community expose limitations in 
old forms of democracy and create needs for renovations. Indeed, as illustrations throughout the preceding discussion have indicated, many ventures in new types of democratic action are already ongoing. For instance, an undertaking such as the World Social Forum would not have found much resonance a generation ago, but today it comprises a sustained transplanetary movement. Meanwhile, proliferating efforts (the present writing among them) to conceptualize and analyze these ongoing trends are helping to consolidate intellectual ground for practical initiatives. Faced with growing discontent in many quarters, elites have become-if only gradually, reluctantly, and partially—more ready to acknowledge so-called "democratic deficits" in many contemporary regulatory arrangements and to explore corrective-if generally limited-reforms such as "good governance," "multistakeholder dialogues," and an expansion of the G8 to include "emergent powers."

Developments to date, as well as the current array of political forces, suggest that reconstructions of democracy for a world of transscalar geography, polycentric governance, and plural community will involve lengthy and difficult struggles. Crises of one kind or another (cultural, ecological, economic, military, or political) may from time to time accelerate future democratic innovations. However, the overall process looks to be one for the long term, with many advances resulting from hard-fought small victories. Such a prospect should not be surprising. Struggles of an earlier era to democratize a social order centered on countries, states, and nations also involved long campaigns and mostly incremental advances. Contemporary democracy promoters therefore probably need likewise to combine patience with resolution, taking solace and strength from the knowledge that every gain contributes to democracy's fruits of greater human dignity, selfrealization, and solidarity. 